\title{
Root excision and dehydration effects on water uptake in four range species
}

\author{
M. BASSIRI, A.M. WILSON, AND B. GRAMI
}

Abstract

Germinating seeds of crested wheatgrass (Agropyron desertorum), Russian wildrye (Elymus junceus), alfalia (Medicago sativa), and cicer milkvetch (Astragalus cicer) were dehydrated for 4 days at $-22 \mathrm{MPa}$, and/or their roots were excised, and used as treated materials. In an experiment in root growth boxes, where the seedlings depended for 60 days on the initial soil water supply, seminal primary and seminal lateral roots of grasses penetrated to the same depth. Both types of roots were similarly effective in taking up water, mainly from the upper $50 \mathrm{~cm}$ of the soil profile. In a sealed pot experiment under favorable moisture conditions, water uptake increased with seedling age up to 34 and $\mathbf{4 1}$ days for crested wheatgrass and Russian wildrye, respectively, and up to the end of the experiment (53 days) for the legume species. Leaf area of grasses was not affected by root excision alone, but it decreased due to the combined effects of root excision and temporary dehydration. Leaf area was generally proportional to water uptake within each species. In all 4 species, root excision and temporary dehydration did not affect transportation rates, while transportation rate decreased as a function of age. Transportation rates were higher in legumes than grasses and were higher in Russian wildrye than crested wheatgrass.

Key Words: crested wheatgrass, Russian wildrye, alfalfa, cicer milkvetch, seedling development

Drought is the most important single factor limiting plant growth in the arid and semiarid regions of the world. Grassland species differ considerably in their abilities to tolerate drought conditions. In trials from 1930 to 1950, Hull (1974) examined 90 species of grasses and reported that crested wheatgrass (Agropyron desertorum) and fairway wheatgrass (A. cristatum) were the most successful species on the drier sites. Harris and Wilson (1970) found that crested wheatgrass was a better competitor for moisture than bluebunch wheatgrass (A. spicatum) because of faster root penetration. Drawe et al. (1975) observed that seedlings of Russian wildrye (Elymus junceus) were not vigorous and grew slowly, and thus were susceptible to moisture stress during emergence and establishment. Bleak and Keller (1974) indicated that germinating seeds of Russian wildrye were less tolerant to dehydration than those of crested wheatgrass.

Among legumes, alfalfa (Medicago sativa) is considered to be drought tolerant. Rumbaugh and Pedersen (1979) showed that alfalfa could survive and remain productive after 23 years of grazing in a region with an average annual precipitation of $200 \mathrm{~mm}$. Peterson (1972) indicated that active roots of alfalfa commonly penetrate to depths of 2.4 to 3.6 meters. On the other hand, cicer milkvetch (Astragalus cicer) is relatively slow in establishment and seems to be adapted to areas of the central Great Plains which receive more than $\mathbf{4 0 0} \mathrm{mm}$ annual precipitation. Information on root development in cicer milkvetch is very limited.

Working on crested wheatgrass and Russian wildrye, Hassanyar

Authors are assistant professor, Department of Plant Science, Isfahan University of Technology, Isfahan, Iran; plant physiologist (deceased), USDA-ARS, Crop Research Lab. Colorado State University, Fort Collins 80253; and post-doctoral researcher, Department of Agronomy and Range Science, University of California, Davis 95616.

Research was supported by Forage and Range Management Research, USDAARS. Authors wish to thank Dr. John Menke for reviewing the manuscript and making helpful suggestions.

Manuscript accepted 2 May 1988. and Wilson (1978) observed that the lateral roots of these species remain quiescent up to a week and this enables the germinating seeds to recover from drought injury which might kill seminal primary roots. They related drought tolerance during germination to embryo morphology and presence of seminal lateral root primordia. Bassiri et al. (1988) showed that temporary dehydration and root excision had pronounced effects on the growth and development of seedlings of crested wheatgrass, Russian wildrye, alfalfa, and cicer milkvetch. The seedlings of grasses and legumes developed seminal lateral roots and replacement tap roots, respectively. These roots supported seedlings for as long as 20 days while soil moisture was limited to the initial irrigation.

The objective of this study was to examine the capability of a single lateral root of the grasses and of replacement tap roots of the legumes to extend in a drying soil profile and to use soil moisture in the deep layers for nearly 2 months after germination. The effects of temporary dehydration during seed germination on subsequent water uptake capacity of these roots was also determined.

\section{Materials and Methods}

Seed source and scarification treatments, methods of temporary dehydration and root excision, and seed germination were the same as described by Bassiri et al. (1988). Germinating seeds of the 4 species were selected and given 1 of the following treatments: (1) Planted directly in moist soil (control treatment), (2) Planted in moist soil after the roots were excised, and (3) Planted in moist soil after being excised and dehydrated at $-22 \mathrm{MPa}$ for 4 days. Such treated materials were used in the following 2 experiments to determine their effects on root extension and on water uptake.

\section{Root Extension Experiment}

Wooden root growth boxes $(9 \times 16 \times 120 \mathrm{~cm}$ inside dimensions) were assembled with screws so that sides could be removed. Polyethylene liners, with holes at the bottom for drainage, were placed inside the boxes to avoid loss of water by evaporation from sides of the soil columns. Boxes were filled with known amounts of autoclaved, air-dry sandy loam soil and a total of 3.7 to 4.0 liters of water was added in 6 or 7 increments during a 3-day period. This amount of water was sufficient to moisten the soil to a water potential of approximately $-0.03 \mathrm{MPa}$ (field capacity).

Twelve of the treated and untreated germinating seeds were planted in each box and covered with $1 \mathrm{~cm}$ of dry soil. After emergence, grass seedlings were thinned to 3 seedlings per box, 1.5 $\mathrm{cm}$ of soil was removed from around the seedling crown, and seedlings were restricted to either the seminal primary root or 1 seminal lateral root by excision of all other roots. About $2 \mathrm{~cm}$ of air-dry soil was then placed around the root and crown of seedlings to support the plants and prevent the development of adventitious roots. The legumes were thinned to 2 seedlings per box, and the soil surface was worked so that it was similar to the air-dry surface of boxes in which the grasses had been planted.

Seedlings were grown for 55 to 60 days in a greenhouse where temperatures fluctuated between 25 and $30^{\circ} \mathrm{C}$, maximum midday photosynthetically active radiation from 300 to $400 \mu \mathrm{EM}^{-2} \mathrm{sec}^{-1}$, relative humidity from 25 to $50 \%$, and daylength was about 14 hours.

At the end of the experiment, 1 side of the box was removed and it was observed that soil columns were not moistened uniformly in 
some of the boxes. Apparently water had channeled down along the side of the soil column and had left pockets of dry soil. Therefore, soil could not be sampled for determination of moisture content. Consequently, the whole experiment was exactly repeated except that the method of moistening the soil columns was improved. Only data from the repeated experiment are reported. In the new procedure, before planting, boxes filled with soil were placed horizontally in large pans of water and soaked for a few hours. Boxes were removed from the water and placed successively at angles of 15,45 , and $90^{\circ} \mathrm{C}$ (about 5 days in each position) to allow drainage of excess water from the soil columns. Because the soil surface had dried somewhat during drainage, an additional 250 $\mathrm{ml}$ of water was added to the soil column just before planting seeds. To ensure the successful emergence of legumes, increments of $50 \mathrm{ml}$ water were added to all treatments whenever the soil surface appeared dry prior to emergence. This additional water for legumes totaled about $500 \mathrm{ml}$.

Finally, 1 side of the box was removed and soil samples were taken from depths of $10,30,50,70,90$, and $110 \mathrm{~cm}$. Water content of the soil samples was determined gravemetrically $\left(105^{\circ} \mathrm{C}\right.$ for 24 hours) for all treatments as well as for the control boxes in which no seedlings had been planted. Roots were washed on $1 \mathrm{~mm}$ screen with a fine spray of water. The length of the longest root in each box was recorded, and roots and shoots were oven-dried $\left(70^{\circ} \mathrm{C}\right.$ for 24 hours) and weighed.

\section{Water Uptake Experiment}

Petri dishes with 3 holes for aeration ( $1 \mathrm{~cm}$ diameter) and 1 hole for seedling growth $(2.5 \mathrm{~cm}$ diameter) were painted dark grey to eliminate light penetration and the growth of algae and mosses beneath the dish. Pots $(15 \mathrm{~cm}$ diameter by $15 \mathrm{~cm}$ depth) were filled to the rim with autoclaved and air-dried soil and irrigated before the petri dishes were sealed into the rims of the pots with butyl rubber sealing compound (Fig. 1). Two centimeters of soil was added over the petri dish and was irrigated to a water potential of about $-0.03 \mathrm{MPa}$. Seeds were planted ( 2 to $3 \mathrm{~mm}$ deep) in the center of each pot so that their roots could extend through the hole in the center of the petri dish. Pots were placed in 2 growth chambers where the conditions for the grasses and legumes were, respectively, 25 and $30^{\circ} \mathrm{C}$ temperature, 40 to 50 and 38 to $42 \%$ relative humidity, and $450-500$ and $800 \mu \mathrm{EM}^{-2} \mathrm{sec}^{-1}$ photosynthetically active radiation. Daylength was 15 hours in both growth chambers. Pots were adequately watered from the top until seedlings in all treatments had emerged. Pots were placed in the growth chamber, and soon after emergence they were subirrigated to

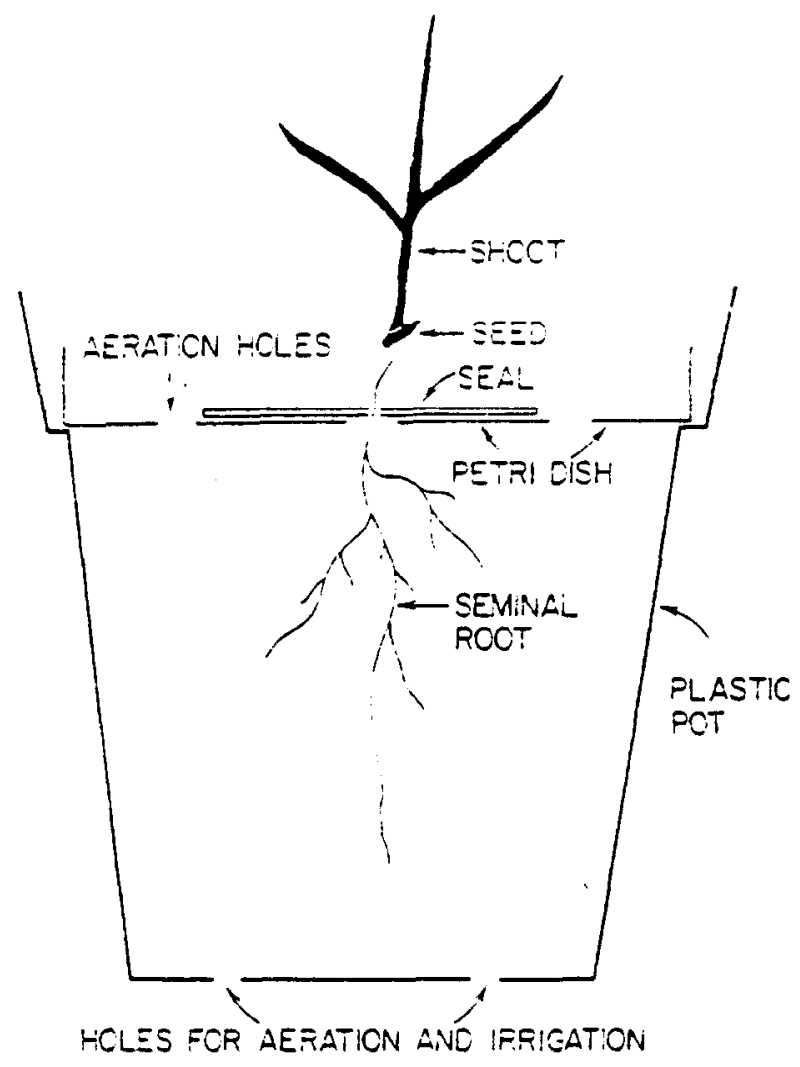

Fig. 1. Drawing of a plastic pot with a grass seedling prepared for water uptake measurement.

maintain a dry soil surface and to prevent adventitious root development in grasses. The amount of water to be added at each irrigation (to increase soil water content to field capacity) was determined by weighing each pot.

When seedlings were between 21 and 30 days old, soil around the crown and the upper $1.8 \mathrm{~cm}$ of the root was removed by washing and seedlings were thinned to 1 per pot. Grass seedlings were restricted to either the seminal primary root or to 1 seminal lateral root. Legume seedlings were supported by the original tap root or by 1 or more replacement tap roots. A seal of aluminum foil was

Table 1. Effects of root excision and temporary dehydration treatments (MPa) on subsequent root depth (cm), root and shoot weight per box ( $m g$ ) of the 4 species, in a 60-day growth performance test in the greenhouse with seedlings limited to the initial soil water supply.

\begin{tabular}{|c|c|c|c|c|c|}
\hline \multicolumn{2}{|c|}{ Treatments } & \multicolumn{4}{|c|}{ Species } \\
\hline Excision ${ }^{1}$ & Dehydration $^{2}$ & $\begin{array}{l}\text { Agropyron } \\
\text { desertorum }\end{array}$ & $\begin{array}{l}\text { Elymus } \\
\text { junceus }\end{array}$ & $\begin{array}{l}\text { Medicago } \\
\text { sativa }\end{array}$ & $\begin{array}{l}\text { Astragalus } \\
\text { cicer }\end{array}$ \\
\hline \multicolumn{6}{|c|}{ Root depth (cm) } \\
\hline $\begin{array}{l}- \\
+ \\
+\end{array}$ & $\begin{array}{r}0 \\
0 \\
-22\end{array}$ & $\begin{array}{l}84 a^{3} \\
90 a \\
82 a\end{array}$ & $\begin{array}{l}84 a \\
89 a \\
63 a\end{array}$ & $\begin{array}{l}117 \mathrm{a} \\
113 \mathrm{a} \\
112 \mathrm{a}\end{array}$ & $\begin{array}{r}112 \mathrm{a} \\
98 \mathrm{~b} \\
90 \mathrm{~b}\end{array}$ \\
\hline \multicolumn{6}{|c|}{ Root weight (mg) } \\
\hline $\begin{array}{l}- \\
+ \\
+\end{array}$ & $\begin{array}{r}0 \\
0 \\
-22\end{array}$ & $\begin{array}{l}219 a \\
209 a \\
169 a\end{array}$ & $\begin{array}{l}234 \mathrm{a} \\
202 \mathrm{a} \\
173 \mathrm{a}\end{array}$ & $\begin{array}{l}4565 a \\
4635 a \\
4034 a\end{array}$ & $\begin{array}{l}3047 a \\
2156 a \\
1747 a\end{array}$ \\
\hline \multicolumn{6}{|c|}{ Shoot weight (mg) } \\
\hline $\begin{array}{l}- \\
+ \\
+\end{array}$ & $\begin{array}{r}0 \\
0 \\
-22\end{array}$ & $\begin{array}{l}2152 \mathrm{a} \\
1773 \mathrm{a} \\
1518 \mathrm{a}\end{array}$ & $\begin{array}{l}2225 \mathrm{a} \\
1701 \mathrm{a} \\
1751 \mathrm{a}\end{array}$ & $\begin{array}{l}4424 a \\
3194 a \\
3924 a\end{array}$ & $\begin{array}{l}3849 a \\
3240 a \\
2702 a\end{array}$ \\
\hline
\end{tabular}

'In the excision treatments, the entire seminal primary roots of grasses and $2 \mathrm{~mm}$ of the root tips of legumes were removed.

${ }^{2}$ Germinating seeds were dehydrated for 4 days in constant humidity trays at $-22 \mathrm{MPa}$.

3eans within each column followed by a similar letter are not significantly different $(P=0.05)$. 
placed around the remaining root and fastened to the upper surface of the petri dish (Fig. 1). A wire support held seedlings in a vertical position.

Measurements for the grasses had to be initiated at an earlier seedling stage than the legumes. Water uptake by roots was determined on each observation date by sealing the aeration holes and weighing the pot and seedling before and after a 24-hr period. Seals were then removed from aeration holes. On each observation date, green leaf blade length was determined for the grasses and number of leaflets was counted for the legumes. After the last water uptake measurement, 10 green leaf blades from each grass seedling and 50 leaflets from each legume seedling were collected for determining area:length ratios and area per leaflet. Area per leaflet was determined with the use of an optical leaf area meter. The resolution of the meter, however, was not adequate for measuring area of narrow grass leaves. Therefore, areas were estimated by placing a transparent 1-mm grid over the flattened leaves and counting the number of grid intersections within the perimeter of the leaf. Leaf area:leaf length ratio for grasses and area per leaflet for legumes were used for estimating seedling leaf area on each of the observation dates. Pots were arranged in a randomized complete block design with 4 replications in the root extension experiment, and 3 and 8 replications in the water uptake experiment for the grasses and legumes, respectively.

\section{Results}

\section{Root Extension Experiment}

Differences in root depth between crested wheatgrass and Russian wildrye and among treatments were not significant (Table 1). Alfalfa roots penetrated to greater depths than cicer milkvetch roots, and original tap roots of cicer milkvetch penetrated to greater $(P=0.01)$ depths than its replacement tap roots.

The inhibitory effect of temporary dehydration on secondary growth of replacement tap roots was not permanent. Under favorable soil moisture conditions, alfalfa replacement tap roots were generally as great as the original tap roots. The combined effects of excision and temporary dehydration on diameter of replacement tap roots varied greatly among seedlings in cicer milkvetch. The formation of 2 or more replacement tap roots was more common in cicer milkvetch than in alfalfa.

Excision and dehydration treatments tended to reduce crested wheatgrass and Russian wildrye root weight (Table 1). Under uniformly favorable moisture conditions in the soil column, semin- al lateral roots grew almost as well as seminal primary roots. Alfalfa had greater $(P=0.01)$ root weight per box than cicer milkvetch.

There were no significant differences caused by treatments in shoot weight per box of any of the 4 species, indicating that seminal lateral roots of grasses and replacement tap roots of legumes were, respectively, similar to seminal primary roots and to original tap roots in their ability to support shoot growth under favorable soil moisture conditions. Shoot weight of cicer milkvetch, however, was significantly more affected by the excision and dehydration treatment than alfalfa.

In boxes planted with grass species, soil water percentages increased $(P=0.01)$ with increasing soil depth (Table 2$)$. In grasses, species and treatment, did not have any significant effect on soil water percentages at the end of the experiment. Soil water percentages were greater in control boxes than in boxes planted with grasses in the upper 3 sampling depths $(10,30$ and $50 \mathrm{~cm})$. The results suggest that roots of grasses used water mainly from the upper $50 \mathrm{~cm}$ of the soil profile and that seminal lateral roots were about as effective in taking up water as were seminal primary roots.

In boxes with alfalfa and cicer milkvetch, differences caused by species, treatments, soil depths, and all two-way interactions were significant $(P=0.05)$ (Table 2). Legume species extracted much more water from the soil profile than grass species. Replacement tap roots that originated from dehydrated germinating seeds of legumes tended to use less water from the $110 \mathrm{~cm}$ depth than did the original tap roots.

\section{Water Uptake Experiment}

In grasses, there were significant differences $(P=0.01)$ in water uptake caused by seedling age, species, and treatment. Water uptake increased with seedling age during the 27- to 34-day interval for crested wheatgrass and 27- to 41-day interval for Russian wildrye and then reached a plateau with little further change (Fig. 2). Seminal primary roots of crested wheatgrass and Russian wildrye were similar in water uptake in this experiment. Seminal lateral roots originated from germinating seeds that had been exposed to temporary dehydration were less effective in water uptake than seminal primary roots in both grass species.

Water uptake in alfalfa and cicer milkvetch significantly increased with increasing seedling age (Fig. 3). Original tap roots of cicer milkvetch had a higher capacity for water uptake than replacement tap roots, especially when replacement tap roots had developed from germinating seeds that had been temporarily dehydrated. In

Table 2. Effects of root excision and temporary dehydration treatments on the soll water content (\%) in various depths of the soll profile (cm) in root growth boxes of 4 species at the end of the 60-day experiment in the greenhouse with seedlings limited to the initial soil water supply.

\begin{tabular}{|c|c|c|c|c|c|c|}
\hline \multirow[b]{2}{*}{ Soil depth } & \multicolumn{6}{|c|}{ Soil water content } \\
\hline & $\begin{array}{l}\text { Not excised } \\
\& \text { not dehyd. }\end{array}$ & $\begin{array}{l}\text { Excised }^{1} \& \\
\text { not dehyd. }\end{array}$ & $\begin{array}{c}\text { Excised \& } \\
\text { dehyd. }{ }^{2}\end{array}$ & $\begin{array}{l}\text { Not excised } \\
\text { \& not dehyd. }\end{array}$ & $\begin{array}{l}\text { Excised \& } \\
\text { not dehyd. }\end{array}$ & $\begin{array}{c}\text { Excised \& } \\
\text { dehyd. }\end{array}$ \\
\hline & & pyron desert & & & lymus junce & \\
\hline \multirow[t]{2}{*}{$\begin{array}{r}10 \\
30 \\
50 \\
70 \\
90 \\
110\end{array}$} & $\begin{array}{l}3.1 \mathrm{a}^{3} \\
7.6 \mathrm{~b} \\
7.8 \mathrm{~b} \\
12.2 \mathrm{c} \\
11.1 \mathrm{bc} \\
15.3 \mathrm{c}\end{array}$ & $\begin{array}{l}4.1 \mathrm{a} \\
8.3 \mathrm{ab} \\
8.2 \mathrm{ab} \\
11.8 \mathrm{bc} \\
13.3 \mathrm{c} \\
14.7 \mathrm{c}\end{array}$ & $\begin{array}{c}4.1 \mathrm{a} \\
6.8 \mathrm{ab} \\
10.7 \mathrm{~b} \\
11.1 \mathrm{~b} \\
15.4 \mathrm{c} \\
17.3 \mathrm{c}\end{array}$ & $\begin{array}{l}3.0 \mathrm{a} \\
6.5 \mathrm{ab} \\
9.8 \mathrm{~b} \\
12.5 \mathrm{c} \\
14.5 \mathrm{c} \\
16.0 \mathrm{c}\end{array}$ & $\begin{array}{l}3.9 \mathrm{a} \\
7.4 \mathrm{~b} \\
10.3 \mathrm{bc} \\
12.3 \mathrm{~cd} \\
15.2 \mathrm{de} \\
17.0 \mathrm{e}\end{array}$ & $\begin{array}{c}3.7 \mathrm{a} \\
7.4 \mathrm{ab} \\
10.4 \mathrm{~b} \\
9.8 \mathrm{~b} \\
15.2 \mathrm{c} \\
15.5 \mathrm{c}\end{array}$ \\
\hline & \multicolumn{3}{|c|}{ Medicago sativa } & \multicolumn{3}{|c|}{ Astragalus cicer } \\
\hline $\begin{array}{r}10 \\
30 \\
50 \\
70 \\
90 \\
110\end{array}$ & $\begin{array}{l}2.7 \mathrm{a} \\
3.4 \mathrm{ab} \\
3.5 \mathrm{ab} \\
3.5 \mathrm{ab} \\
4.0 \mathrm{ab} \\
5.9 \mathrm{~b}\end{array}$ & $\begin{array}{l}2.9 \mathrm{a} \\
3.5 \mathrm{ab} \\
3.5 \mathrm{ab} \\
3.5 \mathrm{ab} \\
3.9 \mathrm{ab} \\
6.7 \mathrm{~b}\end{array}$ & $\begin{array}{l}2.6 \mathrm{a} \\
3.5 \mathrm{ab} \\
3.5 \mathrm{ab} \\
3.5 \mathrm{ab} \\
3.5 \mathrm{ab} \\
6.3 \mathrm{~b}\end{array}$ & $\begin{array}{l}2.9 \mathrm{a} \\
3.8 \mathrm{a} \\
3.8 \mathrm{a} \\
4.1 \mathrm{a} \\
5.1 \mathrm{ab} \\
8.3 \mathrm{~b}\end{array}$ & $\begin{array}{l}3.0 \mathrm{a} \\
4.0 \mathrm{a} \\
4.2 \mathrm{a} \\
5.5 \mathrm{ab} \\
8.7 \mathrm{c} \\
7.5 \mathrm{bc}\end{array}$ & $\begin{array}{r}3.3 \mathrm{a} \\
4.4 \mathrm{a} \\
4.4 \mathrm{a} \\
4.8 \mathrm{a} \\
10.5 \mathrm{~b} \\
10.1 \mathrm{~b}\end{array}$ \\
\hline
\end{tabular}

In the excision treatment, the entire seminal primary roots of grasses and $2 \mathrm{~mm}$ of the root tipes of legumes were removed.

${ }^{2}$ Germinating seeds were dehydrated for 4 days in constant humidity trays at $-22 \mathrm{MPa}$.

${ }^{3}$ Means within each column followed by a similar letter are not significantly different $(P=0.05)$. 


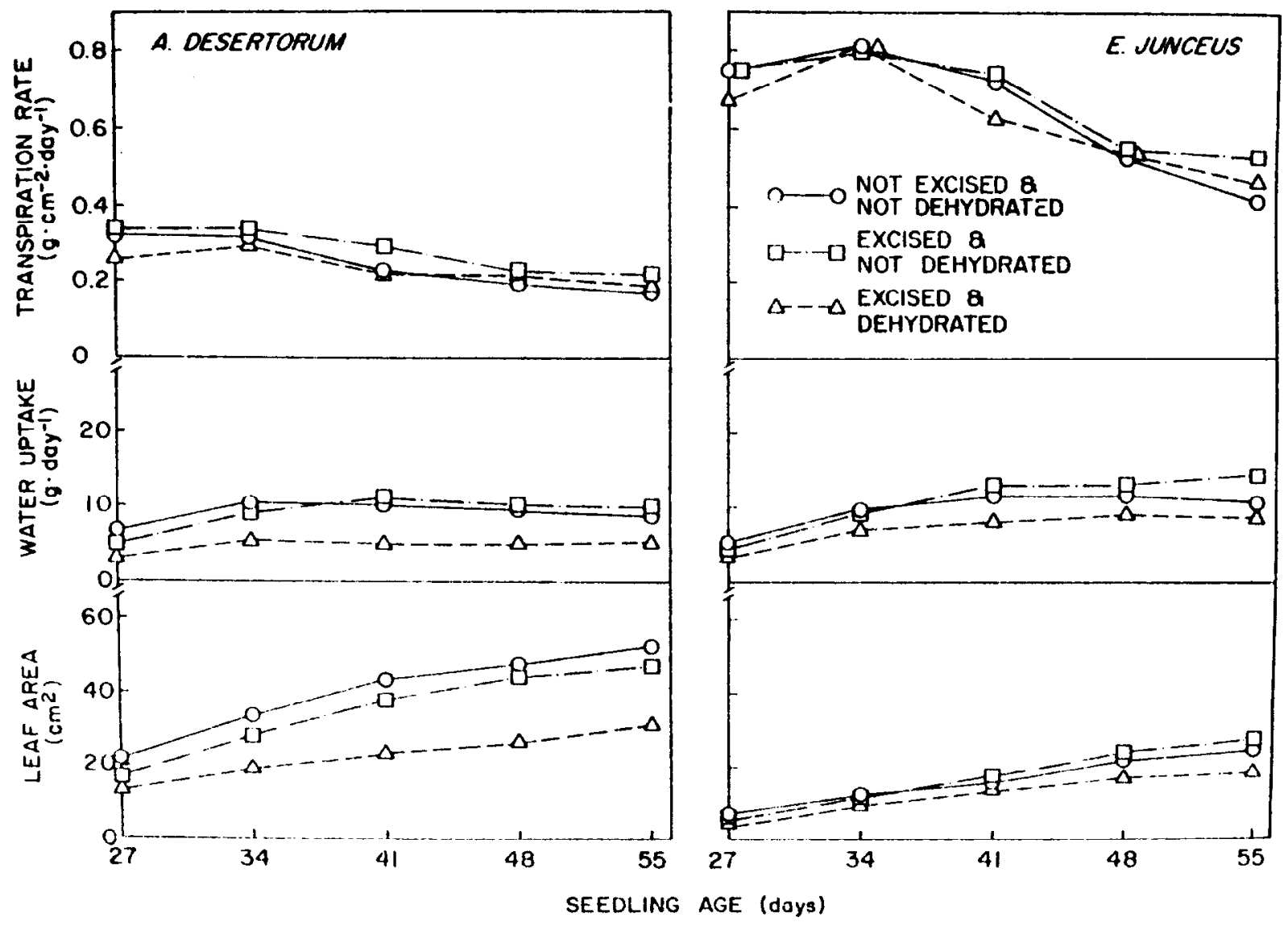

Fig. 2. Effects of root excision and dehydration treatment (-22 MPa) on subsequent leaf area, water uptake, and transpiration rate of wheatgrass (A. desertorum) and Russian wildrye (E. junceus) seedlings.

alfalfa, however, there was little difference in water uptake capacity of original tap roots and replacement tap roots.

Legume seedlings generally had substantially higher rates of water uptake than grass seedlings. Water uptake rates in legumes increased sharply with increasing age of seedlings; whereas in grasses, after about 40 days of age, water uptake reached a maximum and then remained more or less constant until the end of the experiment.

Crested wheatgrass and Russian wildrye generally increased leaf area slowly with increasing seedling age. When seedlings of both grasses were restricted to seminal lateral roots originating from seeds that had not been exposed to temporary dehydration, leaf areas were as great as in seedlings restricted to the seminal primary root. When grass seedlings were restricted to seminal lateral roots originating from temporarily dehydrated seeds, leaf areas were lower than in seedlings restricted to the seminal primary root. Within a species, leaf area generally was proportional to the magnitude of water uptake.

Alfalfa and cicer milkvetch sharply increased their leaf area with increasing seedling age. Treatments did not affect leaf area of alfalfa; but replacement tap roots of cicer milkvetch, especially those originating from seeds that had been temporarily dehydrated, did not support as much leaf area as original tap roots of this species.

Transpiration rates in grasses also decreased with seedling age because of the increase in green leaf-blade area during the period when water uptake was nearly constant. Crested wheatgrass had significantly lower transpiration rates than Russian wildrye. Treatments had little or no effect on transpiration rates. Transpiration rates were higher in legumes than in grasses.

Transpiration rates in the legume species decreased with time, and the decrease was more pronounced in cicer milkvetch than in
Table 3. Effects of seedling growth on the soil water content (\%) at various depths of the soil profile $(\mathrm{cm})$ the end of the 60-day experiment in the greenhouse with seedlings limited to the initial soil water supply.

\begin{tabular}{|c|c|c|c|}
\hline \multirow[b]{2}{*}{ Soil depth } & \multicolumn{3}{|c|}{ Soil water content } \\
\hline & Legumes & Grasses & $\begin{array}{c}\text { No seedling } \\
\text { (Control treatment) }\end{array}$ \\
\hline \multicolumn{4}{|c|}{$1 / 2$} \\
\hline 10 & $2.9 \mathrm{a}$ & $3.6 \mathrm{a}$ & $7.6 \mathrm{~b}$ \\
\hline 30 & $3.9 \mathrm{a}$ & $7.7 \mathrm{~b}$ & $9.8 \mathrm{~b}$ \\
\hline 50 & $3.8 \mathrm{a}$ & $10.3 \mathrm{~b}$ & $11.3 \mathrm{~b}$ \\
\hline 70 & $4.1 \mathrm{a}$ & $12.4 \mathrm{~b}$ & $12.6 \mathrm{~b}$ \\
\hline 90 & $6.0 \mathrm{a}$ & $14.5 \mathrm{~b}$ & $15.6 \mathrm{~b}$ \\
\hline 110 & $7.5 \mathrm{a}$ & $16.0 \mathrm{~b}$ & $16.8 \mathrm{~b}$ \\
\hline
\end{tabular}

'Average of the 2 species and all treatments.

2Means within each soil depth followed by a similar letter are not significantly different from the control treatment ( $P=0.05$ in a $t$-test).

alfalfa. Species and treatments did not have significant effects on transpiration rates.

\section{Discussion}

The seminal lateral roots of grasses were almost as effective as their seminal primary roots (even when germinated seeds had been temporarily dehydrated) in penetrating to and extracting water from the soil profile. In semiarid zones where soil moisture conditions at planting depth rarely are adequate for development of adventitious roots, crested wheatgrass and Russian wildrye may survive for $\mathbf{6 0}$ days, or more, when restricted to only the seminal root system. Thus, if the seminal primary root of germinating seed 


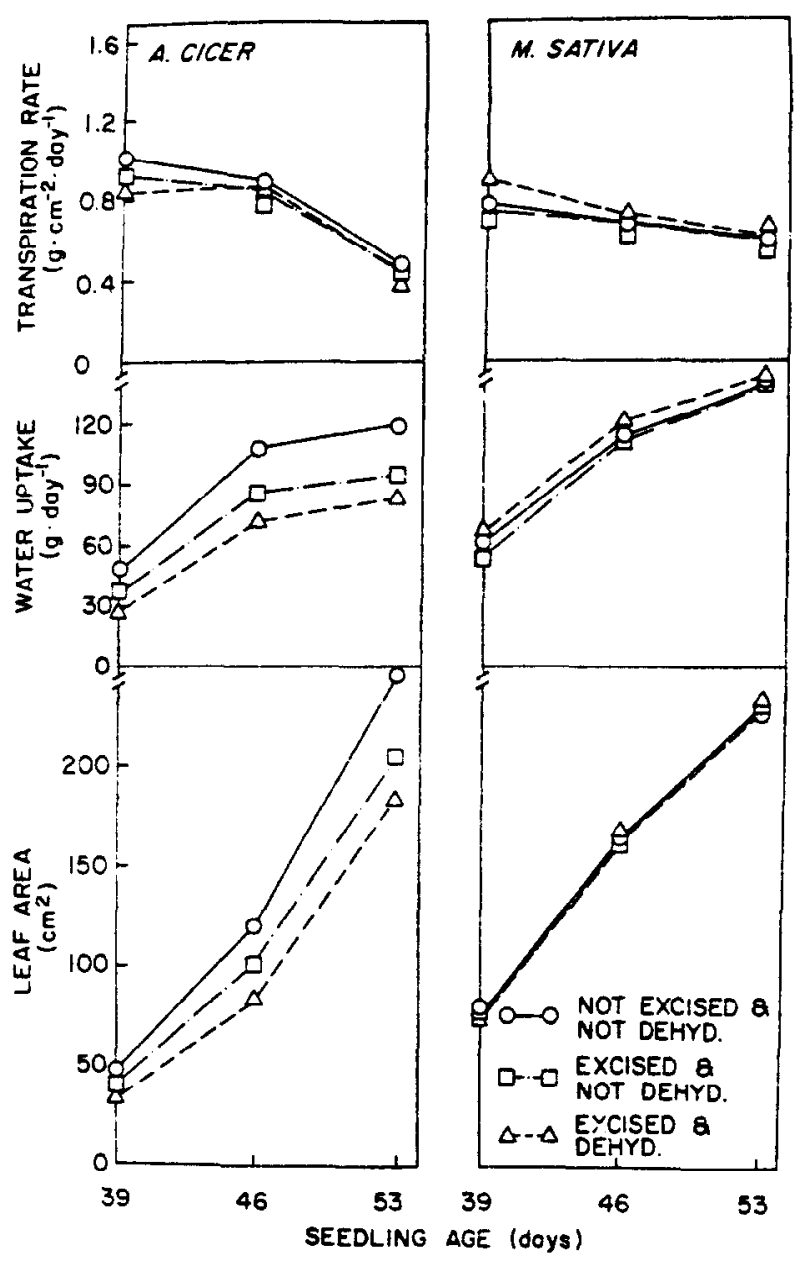

Fig. 3. Effects of root excision and dehydration treatment $(-22 \mathrm{MPa})$ on subsequent leaf area, water uptake, and transpiration rate of alfalfa (M. sativa) and cicer milkvetch (A. cicer) seedlings.

is killed by temporary dehydration, the subsequent development of seminal lateral root(s) would often provide for water and nutrient uptake until weather conditions eventually allow for development of adventitious roots.

Similarly, replacement tap roots of alfalfa and cicer milkvetch were vigorous enough to penetrate to and extract water from deep layers of the soil profile. The legumes, unlike the grasses, do not depend on favorable soil moisture at planting depth for establishment of seedlings; rather, they depend on secondary growth of vascular tissues. Dehydration treatments temporarily delayed secondary growth of roots in many seedlings.

Differences between legumes and grasses in trends of water uptake with increasing age are explained by fundamental differences in the morphology of root growth. Legumes have a vascular cambium which, under favorable growth conditions, continuously produces new xylem and phloem. The new xylem and phloem give an increased water and food transporting capacity, respectively, to the shoot and root. The increased food transporting capacity supports increased growth and total extension of the root. Increased water absorbing and water transporting capacity resulted in a several-fold increase in the water uptake in legumes during a 2-week interval. Erie et al. (1968) reported that mature stands of alfalfa obtained about $46,26,18$, and $10 \%$ of their required moisture from the top $60 \mathrm{~cm}$ of the root zone and from each successive $60 \mathrm{~cm}$ increment, respectively. In cicer milkvetch, the effects of temporary dehydration on subsequent water uptake by replacement tap roots were probably caused by a reduction and delay in total extension and secondary growth of roots. This requires a moist soil profile but does not require moist soil at planting depth. In grasses, the limited amounts of phloem and zylem tissues probably places upper limits on the root extension and on water transportation to the shoot, respectively. The grass species apparently reached their upper limits at about $\mathbf{4 0}$ days after planting. Thereafter, rates of water uptake by individual roots were nearly constant, even though leaf area continued to increase. The effects of temporary dehydration on water uptake by seminal lateral roots probably resulted from inhibition of total extension of roots and reduction in number and size of xylem vessels. In grasses, the inhibitory effects of dehydration may be overcome by production of additional seminal lateral roots (in young seedlings) or of adventitious roots (in older seedlings). Development of new roots requires favorable soil moisture conditions at planting depth as well as in the soil profile.

In the species investigated, transpiration rates decreased with increasing age of seedlings. The decreases in the legumes probably resulted from the limited size of the pot (i.e., limited amount of water available for uptake) as well as mutual shading. Alfalfa also produces smaller leaves under dry conditions as compared to optimum moisture situations. In grasses, leaf area indices were estimated to be much less than 1.0. Therefore, decreases in transpiration rate in grasses probably resulted from the increased growth of leaf area during the interval when water uptake by a single seminal root had reached an upper limit. Grasses had lower transpiration rates than legumes, probably due to differences in leaf diffusion resistance. Frank and Barker (1976) founder higher leaf diffusion resistances in crested wheatgrass than in Russian wildrye, which is consistent with our results.

Kneebone (1972) suggested that in a breeding program for seedling vigor and establishment in grasses, the tolerance of dehydration at seedling stage is an important criterion. Also, Nason et al. (1987) showed the effectiveness of recurrent selection for seedling water uptake and shoot weight in blue grama. Great variations in rate of water uptake among seedlings of both legume and grass species in the present study indicate the potential for selection and development of drought tolerant varieties of these plants. Environmental conditions in the field, especially the amount of water in the root zone, need to be carefully studied to determine if low or high rates of water uptake are advantageous in relation to plant productivity.

\section{Literature Cited}

Bassiri, M., A.M. Wlison, and B. Grami. 1988. Root excision and temporary dehydration effects on emergence and seedling growth of 4 range species. J. Range Manage. 41:

Bleak, A.T., and W. Keller. 1974. Emergence and yield of 6 range grasses planted on 4 days using natural and treated soils. J. Range Manage. 27:225-227

Drawe, L.D., J.B. Grumbles, and J.F. Hopper. 1975. Establishment of Russian wildrye on foothill range in Utah. J. Range Manage. 28:152-154.

Erie, L.J., O.F. French, and K. Harris. 1968. Consumptive use of water by crops in Arizona, p. 5-9. In: Arizona Agr. Exp. Sta., Univ. of Ariz., Tucson, Arizona. Tech. Bull. 169.

Frank, A.B., and R.E. Barker. 1976. Rates of photosynthesis and transpiration and diffusive resistance of 6 grasses grown under controlled conditions. Agr. J. 68:487-490.

Harris, G.A., and A.M. Wilson. 1970. Competition for moisture among seedlings of annual and perennial grasses as influenced by root elongation at low temperatures. Ecology. 51:530-534.

Hassanyar, A.S., and A.M. Wilson. 1978. Drought tolerance of seminal lateral root apices in crested wheatgrass and Russian wildrye. J. Range Manage. 31:254-258.

Hull, A.C., Jr. 1974. Species for seeding arid rangeland in southern Idaho. J. Range Manage. 27:216-218.

Kneebone, W.R. 1972. Breeding for seedling vigor, p. 90-100. In: V.B. Younger, and C.M. McKell (eds.) The biology and utilization of grasses. Academic Press, New York. 
Nason, D.A., R.L. Cuany, and A.M. Wilson. 1987. Recurrent selection in blue grama. I. Seedling water uptake and shoot weight. Crop Sci. 27:847-851.

Peterion, H.B. 1972. Water relationships and irrigation, p. 469-480. In: C.H. Hanson (ed.) Alfalfa science and technology. Amer. Soc. Agron. Madison, Wis.
Rumbaugh, M.D., and M.W. Pedersen. 1979. Survival of alfalfa in 5 semiarid range seedings. J. Range Manage. 32:48-51. 